DOI: 10.34015/2523-4552.2019.1.09

УдК 341.45

Попко В. В.,

кандидат юридичних наук, доцент, доцент кафедри порівняльного і європейського права Інституту міжнародних відносин Київського національного університету імені Тараса Шевченка e-mail: vadympopko@gmail.com ORCID ID: 0000-0001-8358-7721

\title{
ПРИНЦИПИ МІЖНАРОДНОГО СПІВРОБІТНИЦТВА ДЕРЖАВ ІЗ НАДАННЯ ВЗАЄМНОЇ ПРАВОВОЇ ДОПОМОГИ У ТРАНСНАЦІОНАЛЬНОМУ КРИМІНАЛЬНОМУ ПРАВІ
}

У статті розглядаються принципи міжнародного співробітництва держав із надання взаємної правової допомоги у транснаціональному кримінальному праві. Дається теоретико-методологічне обгрунтування цієї проблематики, аналізуються принципи міжнародного співробітництва та їхнє закріплення в міжнародно-правових актах, визначається провідна роль ООН у міжнародному співробітництві держав.

Поняття «взаємна правова допомога держав» розглядається як самостійна категорія міжнародного кримінального права в механізмі міждержавного співробітництва.

Ключові слова: транснациональное уголовное право; принципы; преступность; конвенция; сотрудничество; правовая помощь; взаимодействие государств.

В статье рассматриваются принципы международного сотрудничества государств по предоставлению взаимной правовой помощи в транснациональном уголовном праве. Дается теоретико-методологическое обоснование этой проблематики, анализируются принципы международного сотрудничества, а также их закрепление в международно-правовых актах, определяется ведущая роль $\mathrm{OOH}$ в международном сотрудничестве государств.

Понятие «взаимная правовая помощь государств» рассматривается как самостоятельная категория международного уголовного права в механизме межгосударственного сотрудничества.

Ключевые слова: транснациональное уголовное право; принципы; преступность; конвенция; сотрудничество; правовая помощь; взаимодействие государств.

Постановка проблеми. Сучасні тенденції розвитку міжнародної зло- чинності зумовлюють необхідність активного залучення механізмів на- 
дання та отримання міжнародної правової допомоги у сфері боротьби зі злочинністю, а також цілеспрямованої співпраці світової спільноти в цьому напрямі. Рівень злочинності, а також той факт, що вона давно вже набула транскордонних і транснаціональних форм, визначають необхідність консолідації зусиль міжнародних організацій, держав та їі правоохоронних органів у здійсненні спільних заходів, які забезпечуватимуть ефективність боротьби з цим злом. Провідна роль у правовому регулюванні зусиль держав і світової спільноти із протидії транснаціональній злочинності належить Організації Об’єднаних Націй, особливо в останні десятиліття, коли стало очевидним, що здатність держав самостійно протистояти поширенню міжнародної злочинності не відповідає масштабам злочинів. $\mathrm{y}$ міжнародно-правових актах різного характеру визначається необхідність і принципи міжнародного співробітництва держав із надання правової допомоги, проте в них існує широке розгалуження в підходах до регламентації процедури міжнародної співпраці. Системного вивчення вимагають зміст принципів міжнародного співробітництва, а також їх закріплення в нормах транснаціонального кримінального права, що стосуються видів і форм надання правової допомоги в боротьбі з транснаціональними злочинами.

Аналіз останніх досліджень і публікацій. Співробітництво держав у сфері протидії міжнародній злочинності як спеціальний об'єкт аналізу в міжнародному кримінальному праві належить до числа тих, яким приділяється увага у працях як вітчизняних, так і зарубіжних вчених. У працях М. Бассіоуні, М. Браника,
Н. Бойстера, Г. Верле, М. Ветнцеля, П. Галлі-Харт, Г. Гриффта, Г. Джилберта, М. Костенка, І. Лукашука, В. Маляренка, Е. Мюллер-Рапар, А. Наумова, В. Панова, Д. Понсе, Ю. Решетова, К. Родіонова, Ж. Роні, Н. Сафарова, Д. Спинелліса, М. Таганцева, В. Тертишника, У. Шабаса зазначається безпрецедентне зростання міжнародної злочинності, особливо наприкінці XX - початку XXI ст., і обгрунтовується необхідність удосконалення міжнародно-правових актів та національного законодавства в цій сфері. У спеціальній правовій літературі розробляються концепція, засади, види та механізм співробітництва держав у протидії міжнародній злочинності, а також обгрунтовується необхідність співробітництва в боротьбі зі злочинністю. Особлива увага приділяється проблемам імплементації міжнародних договорів щодо співробітництва, правовим основам нових напрямів міжнародного співробітництва в конкретних сферах (кримінології, кримінального процесу, правосуддя, діяльності правоохоронних органів, Інтерполу, Європолу тощо), зокрема у працях М. Вербенського, О. Волеводза, М. Костенка, Л. Лазутіна, С. Перепьолкіна, М. Смирнова, О. Устинова. Окремі аспекти міжнародного співробітництва держав висвітлені Р. Абдрашитовою, Ю. Аленіним, Р. Баранніком, С. Вознюком, О. Калугіним, С. Кравчуком, Т. Мансуровим, В. Мілінчуком, М. Пашковським, А. Підгородинським, С. Троіцьким, О. Феоктістовою, М. Фроловою, Д. Шенкевичем. Міжнародно-правові форми співробітництва держав із протидії тероризму стали предметом дослідження багатьох вчених. Разом із тим, враховуючи напрацювання, у зв'язку із без- 
прецедентним розвитком транснаціональної злочинності вимагає системного дослідження й удосконалення міжнародне співробітництво держав у різних напрямах, зокрема із надання правової допомоги, у діяльності правоохоронних органів, надання інформації, доказів, проведення кримінального переслідування, арешту злочинців тощо. Теоретичною й методологічною основою вивчення цих питань стали праці вітчизняних і зарубіжних вчених, зокрема Д. Анцилотті, М. Баймуратова, М. Бассіоуні, П. Біленчука, І. Блищенко, А. Боссарда, М. Буроменського, В. Буткевича, М. Вербенського, Г. Верле, М. Гнатовського, А. Дмитрієва, Н. Зелінської, Л. Іногамової-Хегай, А. Кассезе, О. Кибальника, О. Козаченка, М. Костенка, І. Лукашука, А. Наумова, В. Панова, В. Пелла, Т. Сироїд, Ю. Трунцевського, Дж. Шварценбергера та інших, в яких вивчається феномен транснаціональної злочинності, концепція транснаціонального злочину, його ознаки та види, питання криміналізації транснаціональних злочинів та юрисдикція, структура організованої злочинності, окремі складові механізму функціонування злочинних угрупувань, питання кримінального переслідування та видачі, узагальнюється міжнародний досвід співробітництва в боротьбі $з$ цим видом злочинності тощо.

Постановка завдання. Вивчення системи принципів взаємодії та співробітництва держав у сучасному світі з питань надання правової допомоги у сфері боротьби з транснаціональною злочинністю, а також розкриття їхнього змісту.

Виклад основного матеріалу.

Характер сучасної транснаціональної злочинності вимагає глоба- льного реагування на основі широкого міжнародного співробітництва у різних сферах відносин.

В основі сучасного міжнародного співробітництва держав закладені принципи, закріплені в Статуті ООН [1], Декларації про принципи міжнародного права, що стосуються дружніх відносин і співробітництва між державами відповідно до Статуту ООН від 24 жовтня 1970 р. [2], широко визнані в міжнародних відносинах, а основоположні норми міжнародного кримінального права й міжнародних конвенцій у сфері транснаціональної злочинності включені в національні правові системи. Зобов'язання держав співробітничати одна з одною й надавати правову допомогу $є$ імперативним правилом протягом десятиліть. Співробітництво держав у всіх сферах, у тому числі в кримінальній, повинно здійснюватися незалежно від розбіжностей у політичних, економічних і соціальних системах і в той же час відбуватися 3 дотриманням державного суверенітету. Проте, як пише М. Костенко, «всебічне співробітництво держав у боротьбі з міжнародними злочинами вимагає належного доктринального відображення в науці сучасного міжнародного права. У наш час має місце недостатня опрацьованість в академічному плані всього комплексу міжнародно-правових питань із зазначеної проблематики, невідповідність рівня конвенційного забезпечення завдання міжнародного правосуддя вимогам міжнародної спільноти, внаслідок чого знижується ефективність боротьби 3 міжнародними злочинами» $[3$, с. 7].

Поняття «взаємна правова допомога держав» слід розглядати як самостійну категорію міжнародного 
кримінального права в механізмі міждержавного співробітництва, яка представляє «установлення варіантів взаємоузгоджених дій держав, втілених у нормативних формулюваннях обсягу правової допомоги, що можна позначити в якості юридичного змісту» [4]. Право надання міжнародної правової допомоги і співробітництво в кримінальних справах охоплює правила про транскордонне здійснення міжнародного кримінального права, особливо про екстрадицію, надання допомоги щодо виконання вироків, передача процесуальних дій іншим суб'єктам та інших формах правової допомоги - таких, як надання взаємного сприяння у збиранні доказів (М. Бассіоуні, Д. Понсе, П. Галлі-Харт, Е. Мюллер-Рапар, Д. Спинелліса). Дані правила $є$ виключно процесуальними і не створюють міжнародної кримінальної відповідальності. Як зазначає Г. Верле, «не володіючи власними виконавчими органами, особливо міжнародні кримінальні суди залежать від співробітництва держав (так зване вертикальне співробітництво). більшості випадків, однак, йдеться про співробітництво між державами (так зване горизонтальне співробітництво)» $[5$, с. 166].

У нормах міжнародного кримінального права і в законодавстві окремих держав інколи вживають й інші терміни для позначення правової допомоги у кримінальних справах. Зокрема, у назві Європейської конвенції про взаємну допомогу у кримінальних справах від 20 квітня 1959 р. [6] ужито термін «взаємна допомога», натомість у ст. 541 КПК України йдеться про «міжнародну правову допомогу». Обидва правові акти характеризують одне явище, і конфлікт у назвах суттєвого значення немає. Смислове навантаження для позначення правового явища зосереджене у словосполученні «правова допомога». У Конвенції Організації Об’єднаних Націй проти транснаціональної організованої злочинності від 15 листопада 2000 р. [7] вживають термін «взаємна правова допомога», щоб підкреслити зміст і обсяг поведінки суб'єктів міжнародного права та наголосити на необхідності виконання державами одноманітного комплексу дій для забезпечення міжнародного співробітництва. Вживання в національному законодавстві терміна «міжнародна» засвідчує лише характер правової допомоги [8, с. 166].

Норми транснаціонального кримінального права, спрямовані на боротьбу зі злочинністю, визначають принципи міжнародного співробітництва держав із надання правової допомоги у цій сфері. Як зазначає М. Костенко, «необхідність правового оформлення міжнародного співробітництва держав у боротьбі зі злочинністю зумовлена характером міжнародних злочинів, які представляють небезпеку не тільки для окремих держав, а й для усієї світової спільноти» [3, с. 243]. Якою б не була правова форма закріплення принципів, до якої б форми міжнародного співробітництва вона не належала, ці принципи завжди є нормами загального й керівного значення, основою процесу правозастосування в усіх напрямах взаємодії держав, у тому числі й при наданні взаємної правової допомоги при розкритті транснаціональних злочинів.

У цілому міжнародне співробітництво у сфері транснаціонального кримінального права, і зрозуміло, його складова - надання правової 
допомоги - базується на принципах міжнародного кримінального права, які відображені в договорах, конвенціях, деклараціях, пактах, національному законодавстві. Як зазначає професор Н. Зелінська, «необхідність протидії злочинності, яка все більше інтернаціоналізується, зумовила укладення конвенцій, що передбачають спеціальні умови міжнародного співробітництва у протидії певним видам злочинності» $[9$, с. 198].

Важливими принципами міжнародного співробітництва з надання правової допомоги є взаємність співробітництва, добровільність здійснення, дотримання національного суверенітету і безпеки, можливість застосування іноземного законодавства (уступка суверенітету), відповідність прохання запитуючої держави законодавству запитуваної держави, рівність повноважень компетентних органів, забезпечення правового захисту, реалізація умов договору з допомогою національного законодавства, дія міжнародного договору тільки на території держав - його учасників, співробітництво на основі права, передбаченого міжнародним договором, дотримання законності.

Принцип взаємності й добровільності співробітництва $€$ одним із визначальних у транснаціональному кримінальному праві. Він не завжди знаходить своє безпосереднє закріплення у вигляді окремої правової норми, проте випливає зі змісту міжнародно-правових актів. Взаємність у відносинах держав при здійсненні міжнародного співробітництва у сфері надання правової допомоги має виявлятися у двосторонньому та сумлінному виконанні ними взятих на себе зобов'язань у рамках, передбачених міжнародними договорами про співпрацю. Слід зазначити, що взаємність має місце не лише при співробітництві на основі договору, а й за умови його відсутності. Добровільність же виявляється, насамперед, під час підписання державою відповідного договору при його укладанні або приєднанні до вже існуючого.

Зміст принципу поваги й дотримання суверенітету держав полягає в тому, що кожна державаучасниця міжнародного співробітництва із надання правової допомоги не може втручатися у внутрішні справи іншої держави, повинна утримуватися від застосування сили проти територіальної цілісності, політичної незалежності іншої держави. Погроза силою або їі застосування $€$ порушенням міжнародного права і жодним чином не може використовуватись в якості засобу врегулювання міжнародних проблем. Цей принцип закладений у всіх конвенціях, що стосуються боротьби з транснаціональною злочинністю, і порушення цієї вимоги є підставою у відмовленні запитуваній державі у проханні про надання правової допомоги. Проте, як зазначає Р. Бараннік, «запитуючи правову допомогу, держава змушена поступатися частиною свого суверенного права розслідувати злочини, що зазіхають на їі інтереси, а також карати винуватих осіб» $[10$, с. 16]. При наданні правової допомоги у кримінальних справах наглядно виявляється взаємодія норм міжнародного кримінального права і національного законодавства, їх взаємопроникнення і взаємодоповнення для досягнення певних цілей, зокрема в боротьбі з транснаціональною злочинністю.

Важливе місце серед принципів надання правової допомоги посіда- 
ють взаємне визнання юридичної сили офіційних документів між державами, що співпрацюють, оперативність надання правової допомоги, а також принцип рівності доказів, отриманих за кордоном у порядку правової допомоги [11, с. 89]. За дотримання всіх необхідних вимог направлення і виконання запиту, докази, направлені із-за кордону, оцінюються так само, якби вони були отримані на території запитуваної держави. Щодо допиту осіб, за загальним правилом надання правової допомоги, необхідна їх згода. Відносно обсягів правової допомоги, то в більшості міжнародних конвенцій він схожий і стосується зазвичай процесуальних (вручення документів, проведення допиту) і слідчих дій (огляд місце скоєння злочину, розшук злочинців), здійснення кримінального переслідування особи, передачі предметів (речових доказів), конфіскації майна, надання і обмін інформацією та інше.

Окрім Статуту ООН, у якому закріплені основоположні принципи міжнародного права, принципи надання правової допомоги у кримінальних справах, як вже зазначалось, містяться в універсальних конвенціях та численних міжнародних угодах, що містять положення про співробітництво в боротьбі з тим чи іншим видом транснаціональної злочинності й доповнюють одна одну в цій сфері, а також у національному законодавстві. Важливе значення мають і двосторонні договори про взаємну правову допомогу, що найбільшу активність у цих відносинах проявляють США. Ці договори передбачають юридичну допомогу 3 широкого кола питань, включаючи надання інформації про банківські рахунки, надання копій певних державних документів, включаючи доповіді поліції, «замороження» й репатріацію вкраденої власності країн-учасниць договору.

Свого часу важливим кроком у розвитку регламентації надання правової допомоги в кримінальних справах стала Європейська конвенція про взаємну допомогу у кримінальних справах від 20 квітня 1959 р. [6], яка згодом була доповнена двома протоколами, викликаними практичною необхідністю, та Конвенція про правову допомогу і правові відносини у цивільних, сімейних та кримінальних справах від 22 січня 1993 р. (Мінська конвенція) [12]. Зазначені конвенції заклали основу співробітництву держав, на що звертає увагу професор Н. Бойстер: «Договори про взаємну правову допомогу заклали основу для інформаційного обміну за допомогою заходів, що передбачені статтею 22 Європейської конвенції про взаємну правову допомогу у кримінальних справах» [13, с. 213].

У наш час важливу роль у становленні та розвитку взаємної правової допомоги відіграє Європейська конвенція про передачу провадження у кримінальних справах від 15 травня 1972 р. [14]. Згідно зі ст. 6 Конвенції, якщо особу підозрюють у вчиненні злочину, передбаченого законодавством договірної держави, ця держава може звернутися до іншої договірної держави із клопотанням про проведення розслідування у випадках та на умовах, передбачених цією Конвенцією. Серед цих умов, за яких держава може заявити відповідне клопотання, важливими є: постійне місце проживання у запитуваній державі підозрюваної особи; громадянство запитуваної держави підозрюваної особи або якщо ця 
держава $\epsilon$ країною його походження; відбування покарання, за яке передбачено позбавлення волі, або якщо воно має відбуватися в запитуваній державі підозрюваної особи; якщо в запитуваній державі за той самий злочин або за інші злочини проти підозрюваної особи порушено кримінальне переслідування; якщо держава вважає, що передача провадження виправдана інтересами встановлення істини, i, зокрема, що найсуттєвіші докази є в запитуваній державі; якщо держава вважає, що присутність на судовому засіданні підозрюваної особи не може бути забезпечена в запитуючій державі, у той час як її присутність на судовому засіданні може бути забезпечена в запитуваній державі; якщо вона вважає, що вона не може сама виконати вирок, у разі винесення такого, навіть з використанням екстрадиції, у той час як запитувана держава спроможна це зробити.

Серед джерел транснаціонального кримінального права слід виокремити й інші міжнародні, у тому числі й регіональні, документи, у яких містяться положення щодо взаємодії держав із надання правової допомоги: Конвенція Організації Об'єднаних Націй про боротьбу проти незаконного обігу наркотичних засобів і психотропних речовин від 20 грудня 1988 р. [15], Міжнародна конвенція про боротьбу з актами ядерного тероризму від 13 квітня 2005 р. [16], Конвенція 0рганізації Об'єднаних Націй проти корупції від 31 жовтня 2003 р. [17], Конвенція про кіберзлочинність, ухвалена Радою Європи 23 листопада 2001 р. [18], Європейська конвенція щодо відшкодування збитку жертвам насильницьких злочинів від 24 листопада 1983 р. [19], а також численні двосто- ронні угоди про правову допомогу. Кожен із зазначених юридичних актів у рамках їх регулятивного впливу сприяють створенню системи співробітництва держав у протидії злочинності.

Чільне місце серед джерел транснаціонального кримінального права посідає Конвенція Організації Об'єднаних Націй проти транснаціональної організованої злочинності від 15 листопада 2000 р., ухвалена Резолюцією 55/25 Генеральної Асамблеї ООН [7] (набрала чинності у вересні 2003 р., Україна ратифікувала цю Конвенцію із застереженнями і заявами Законом від 4 лютого 2004 р.). Ця Конвенція містить положення про особливості співробітництва держав у сфері взаємної допомоги у кримінальних справах для окремих категорій злочинів. Йдеться, у першу чергу, про транснаціональні злочини, які являють собою «серйозні злочини», що «мають транснаціональний характер і вчинені за участю організованої злочинної групи» (ст. 3 п. 1). На відміну від раніше прийнятих актів щодо співробітництва держав у боротьбі зі злочинністю, дана Конвенція $\mathrm{OOH}$ 2000 р. суттєво розширює коло тих злочинів, на які поширюється її дія, i тим самим - межі міжнародного співробітництва держав із надання правової допомоги. Режим такого співробітництва поширюється на будь-які злочини, здійснені транснаціональними організованими злочинними угрупуваннями, будь-то тероризм, піратство, захоплення заручників, вбивства, пограбування, наркобізнес, торгівля людьми, корупція, відмивання коштів, перешкоджання правосуддю тощо. Головними методами боротьби з транснаціональною організованою злочинністю, як і раніше, 
задовго до початку глобалізації, $\epsilon$ видача осіб та взаємна правова допомога, якій у Конвенції присвячена ст. 18 «Взаємна правова допомога».

Відповідно до закріпленого в Конвенції принципу взаємності, «Держави-учасниці надають одна одній найширшу взаємну правову допомогу в розслідуванні, кримінальному переслідуванні та судовому розгляді у зв'язку зі злочинами, що охоплюються цією Конвенцією, як це передбачено у статті 3, і на взаємній основі надають одна одній іншу аналогічну допомогу, якщо запитуюча Держава-учасниця має розумні підстави підозрювати, що злочин, зазначений у пункті 1 (a) чи (b) статті $3, \epsilon$ транснаціональним за своїм характером i, у тому числі, що потерпілі, свідки, доходи, засоби вчинення злочинів або докази щодо таких злочинів перебувають у запитуваній Державі-учасниці, а також що до вчинення цього злочину причетна організована злочинна група» (п. 1). Взаємна правова допомога надається в обсязі, максимально можливому відповідно до законів, договорів, угод і домовленостей запитуваної держави-учасниці, щодо розслідування, кримінального переслідування і судового розгляду у зв'язку зі злочинами, за вчинення яких до відповідальності у запитуючій Державіучасниці може бути притягнута юридична особа відповідно до статті 10 цієї Конвенції (п. 2).

Щодо обсягів правової допомоги, то в більшості міжнародних конвенцій він схожий і стосується зазвичай процесуальних (вручення документів, проведення допиту) і слідчих дій (огляд місця скоєння злочину, розшук злочинців), здійснення кримінального переслідування особи, передачі предметів (речових доказів), конфіскації майна, надання i обмін інформацією та інше.

Взаємна правова допомога може включати різні види і обсяги у процесуальній сфері, слідчих діях та інших сферах та може запитуватися 3 метою: a) одержання показань свідків або заяв від окремих осіб; b) вручення судових документів; c) проведення обшуку і здійснення виїмки або арешту; d) огляд об'єктів і ділянок місцевості; е) надання інформації, речових доказів і оцінок експертів; f) надання оригіналів або завірених копій відповідних документів і матеріалів, включаючи урядові, банківські, фінансові, корпоративні чи комерційні документи; g) виявлення або відстеження доходів від злочинів, майна, засобів вчинення злочинів або інших предметів 3 метою доведення; h) сприяння добровільній явці відповідних осіб до органів запитуючої держави-учасниці; i) надання будь-якого іншого виду допомоги, що не суперечить внутрішньому законодавству запитуваної держави-учасниці (п. 3). Щодо передачі кримінального переслідування, то в юридичній літературі існує думка, що ці дії не охоплюються обсягом правової допомоги. Вірогідно, це пов'язано з його значенням і складністю виконання на практиці. Слід зазначити, що коли держава передає кримінальне переслідування, мова йде про іноземного громадянина, який здійснив злочин на її території і сховався у запитуючій державі.

Взаємна правова допомога передбачає, що компетентні органи держави-учасниці можуть без попереднього прохання передавати інформацію, що стосується кримінальноправових питань, компетентному 
органу в іншій державі-учасниці у тих випадках, коли вони вважають, що така інформація може надати допомогу цьому органу у здійсненні чи успішному завершенні розслідування і кримінального переслідування (п. 4).

У Конвенції визначено, що держави-учасниці не вправі відмовляти у наданні взаємної правової допомоги на підставі банківської таємниці (п. 8). Проте можуть відмовити у такій допомозі на підставі відсутності обопільного визнання відповідного діяння злочином. Однак запитувана держава-учасниця може надати допомогу, обсяг якої вона визначає на власний розсуд, незалежно від того, чи є відповідне діяння злочином відповідно до внутрішнього законодавства запитуваної держави-учасниці (п. 9).

Детальне регулювання відносин щодо передачі особи на територію запитуваної держави, згідно з Конвенцією, передбачає, що особа, яка перебуває під вартою або відбуває термін тюремного ув'язнення на території однієї держави-учасниці та присутність якої в іншій державіучасниці необхідна з метою встановлення особи, давання показань або надання іншої допомоги в одержанні доказів для розслідування, кримінального переслідування або судового розгляду у зв'язку зі злочинами, що охоплюються цією Конвенцією, може бути передана 3 дотриманням певних умов: згода особи або згода обох держав в особі компетентних органів (п. 10).

Важливими $є$ й інші питання, врегульовані Конвенцією ООН 2000 р., зокрема визначення центрального органу з відповідними повноваженнями й відповідального за одержан- ня і виконання прохань про надання взаємної правової допомоги. Цей орган має забезпечити оперативне й належне виконання або перепровадження отриманих прохань. Конвенція вимагає належного оформлення прохань (письмова або усна форма, згодом підтверджена) з дотримання вимог законодавства, конфіденційності тощо.

Також слід наголосити, що кожна запитувана держава, виходячи із зазначених принципів і свого законодавства, вправі відмовити у виконанні відповідних дій у порядку надання правової допомоги. Як правило, це перш за все стосується забезпечення безпеки і суверенітету запитуваної держави, громадського порядку, а також у випадках невідповідності запиту про правову допомогу законодавству запитуваної держави (п. 21). Така обставина зумовлена об'єктивними засадами, які полягають у принциповій різниці між нормами національного права держав, що належать до різних правових систем. Тому вкрай важливо, щоб запит про конкретні дії у порядку надання правової допомоги, крім того, щоб був правильно оформленим, містив посилання на норми законодавства, та, головне, на норми міжнародного кримінального права. Можливість застосування в міжнародному кримінальному праві при здійснення правової допомоги іноземного законодавства (уступка суверенітету), різниця в законодавствах сторін може не мати значення для повноцінного співробітництва. Існують ситуації, коли саме застосування іноземного законодавства є єдиною можливістю виконання запиту про правову допомогу. Однак, це право, а не обов'язок запитуваної держави. Про- 
те, за загальним правилом, при наданні правової допомоги застосовується законодавство виконуючої держави.

Держави-учасниці не можуть відмовляти у виконанні прохання про взаємну правову допомогу лише на тій підставі, що злочин вважається також пов'язаним із податковими питаннями (п. 22), а будь-яка відмова в наданні взаємної правової допомоги обов'язково мотивується (п. 23). У певних випадках надання взаємної правової допомоги може бути відстрочено запитуваною державоюучасницею на тій підставі, що це перешкодить здійснюваному розслідуванню, кримінальному переслідуванню або судовому розгляду (п. 25). У ході провадження або надання допомоги при здійсненні розслідування, кримінального переслідування або судового розгляду на території запитуючої держави-учасниці, можуть залучатися свідки, експерти або інші особи за їх згодою і з певними гарантіями їхньої особистої безпеки (п. 27).

Контроль над виконанням положень Конвенції здійснює Конференція учасників Конвенції, яка оцінює виконання положень Конвенції країнами-учасницями й пропонує подальші рекомендації відносно розвитку міжнародного співробітництва у боротьбі з транснаціональною злочинністю. Відносно виконання Конвенції слід звернути увагу, що в ній не передбачені конкретні зобов'язання держав щодо звітності про результати імплементації Конвенції, відсутній механізм вимог надавати таку інформацію: державиучасниці приводять свої національні законодавства у відповідність з положеннями Конвенції на свій розсуд.

\section{Висновки i перспективи} подальших досліджень. Для здійснення заходів із попередження транснаціональної злочинності і боротьби з нею абсолютно необхідно міжнародне співробітництво держав на універсальному рівні 3 надання правової допомоги і суворе дотримання принципів міжнародного кримінального права. Всебічне регулювання міжнародного співробітництва із протидії транснаціональній злочинності переживає період становлення. На шляху до універсалізації правового регулювання боротьби 3 транснаціональними злочинами основними завданнями $€$ закріплення міжнародних стандартів y національних практиках кримінального процесу, удосконалення співробітництва у наданні взаємної правової допомоги, координація роботи національних правоохоронних органів. Оскільки міжнародні конвенції містять норми загального характеру, їх регулятивні можливості дещо обмежені, ефективне міжнародне співробітництво $є$ можливим завдяки механізму, закріпленому в нормах міжнародного кримінального права та національному законодавстві держав. За допомогою норм міжнародного кримінального права формуються лише загальні принципи взаємодії держав під час надання правової допомоги. Виконання ж конкретного доручення має здійснюватися відповідно до вимог національного законодавства та 3 обов'язковим урахуванням застережень, зроблених при ратифікації відповідного міжнародно-правового документа. 


\section{Список використаних джерел}

1. Статут Організації Об'єднаних Націй від 26 червня 1945 p. URL: https://zakon.rada.gov.ua/laws/show/995_010 (дата звернення: 10.05.2019)

2. Декларація про принципи міжнародного права, що стосуються дружніх відносин та співробітництва між державами відповідно до Статуту Організації Об'єднаних Націй від 24 жовтня 1970 p. URL: https://zakon.rada.gov.ua/laws/show/995_569 (дата звернення: 20.05.2019).

3. Костенко Н. И. Международное уголовное право: современные теоретические проблемы. Москва : Юрлитинформ, 2004. 448 с.

4. Лазутин Л.А. Виды правовой помощи по уголовным делам: вопросы теории». Журнал российского права. 2008. № 7. С. 40-48.

5. Верле Г. Принципы международного уголовного права: учебник; пер. с англ. С. В. Саяпина. Одесса: Фенікс. Москва: ТрансЛит, 2011. 910 с.

6. Європейська конвенція про взаємну допомогу у кримінальних справах від 20 квітня 1959 p. URL: https://zakon.rada.gov.ua/laws/show/995_036 (дата звернення: 20.05.2019).

7. Конвенція ООН проти транснаціональної організованої злочинності, ухвалена Резолюцією 55/25 Генеральної Асамблеї від 15 листопада 2000 p. URL: http://zakon.rada.gov.ua/laws/show/995_789 (дата звернення: 20.05.2019).

8. Теорія кримінального переслідування / В.А.Гринчак, І.Я.Заяць, В. І. Петлюк, Г. М. Федущак-Паславська. Львів : ЛНУ ім. І. Франка, 2017. 207 с.

9. Зелинская Н. А. Международные преступления и международная преступность : монография; Одесская национальная юридическая академия. Одесса : Юридична література, 2006. 568 с.

10. Бараннік Р. В. Принципи міжнародного співробітництва та міжнародної правової допомоги під час кримінального провадження. Вісник кримінального судочинства. 2017. № 2. С. 11-18.

11. Устинов А. В. Юридическая сила доказательств, полученных на территории иностранного государства при международном сотрудничестве по уголовным делам. Вестник Российского университета дружбы народов. Серия: Юридические науки. 2010. № 1. С. 89-98.

12. Конвенція про правову допомогу і правові відносини у цивільних, сімейних та кримінальних справах від 22 січня 1993 р. URL: https://zakon.rada.gov.ua/ laws/show/997_009 (дата звернення: 18.05.2019).

13. Boister N. An Introduction to Transnational Criminal Law. Oxford : University Press, 2012. 512 p.

14. Європейська конвенція про передачу провадження у кримінальних справах від 15 травня 1972 р. URL: https://zakon.rada.gov.ua/laws/show/994_008 (дата звернення: 19.05.2019)

15. Конвенція Організації Об'єднаних Націй про боротьбу проти незаконного обігу наркотичних засобів і психотропних речовин від 20 грудня 1988 p. URL: https://zakon.rada.gov.ua/laws/show/995_096 (дата звернення: 20.05.2019).

16. Міжнародна конвенція про боротьбу з актами ядерного тероризму від 13 квітня 2005 p. URL: https://zakon.rada.gov.ua/laws/show/995_d68 (дата звернення: 20.05.2019).

17. Конвенція Організації Об'єднаних Націй проти корупції від 31 жовтня 2003 р. URL: https://zakon.rada.gov.ua/laws/show/995_c16 (дата звернення: 20.05.2019).

18. Конвенція про кіберзлочинність, ухвалена Радою Європи 23 листопада 2001 р. URL: https://zakon.rada.gov.ua/laws/show/994_575 (дата звернення: 20.05.2019).

19. Європейська конвенція щодо відшкодування збитку жертвам насильницьких злочинів (ETS N 116) від 24 листопада 1983 p. URL: https://zakon.rada.gov.ua/ laws/show/994_319 (дата звернення: 20.05.2019). 


\section{References}

1. Statut Orhanizatsii Obiednanykh Natsii vid 26 chervnia 1945 r. <https://zakon.rada.gov.ua/laws/show/995_010> [in Ukrainian].

2. Deklaratsiia pro pryntsypy mizhnarodnoho prava, shcho stosuiutsia druzhnikh vidnosyn ta spivrobitnytstva mizh derzhavamy vidpovidno do Statutu Orhanizatsii Obiednanykh Natsii vid 24 zhovtnia 1970 r. 1970 <https://zakon.rada.gov.ua/ laws/show/995_569> [in Ukrainian].

3. Kostenko, N. I. (2004). Mezhdunarodnoe ugolovnoe pravo: sovremennye teoreticheskie problemy. Moskva: Jurlitinform [in Russian].

4. Lazutin, L. A. (2008). Vidy pravovoj pomoshhi po ugolovnym delam: voprosy teorii. Zhurnal rossiyskogo prava, 7. 40-48. [in Russian].

5. Gerhard Verle (2011). Principy mezhdunarodnogo ugolovnogo prava. Uchebnik. Od. Feniks. Moskva: TransLit [in Russian].

6. Yevropeiska konventsiia pro vzaiemnu dopomohu u kryminalnykh spravakh vid 20 kvitnia 1959 r. <https://zakon.rada.gov.ua/laws/show/995_036> [in Ukrainian].

7. Konventsiia OON proty transnatsionalnoi orhanizovanoi zlochynnosti, ukhvalena Rezoliutsiieiu 55/25 Heneralnoi Asamblei (15 lystopada 2000 r.) Ofitsiinyi veb-sait Verkhovnoi Rady Ukrainy. <http://zakon.rada.gov.ua/laws/show/995_789> [in Ukrainian].

8. Hrynchak, V. A., Zajac, I. Ja., Petliuk, V. I., Fedushchak-Paslavska, H. M. (2017). Teorija kryminalnoho peresliduvannia. Lviv: LNU im. I. Franka [in Ukrainian].

9. Zelinskaja, N.A. (2006). Mezhdunarodnye prestuplenija i mezhdunarodnaja prestupnost': monografija. Odesa: Juridichna literatura [in Russian].

10. Barannik, R.V. (2017). Pryntsypy mizhnarodnoho spivrobitnytstva ta mizhnarodnoi pravovoi dopomohy pid chas kryminalnoho provadzhennia. Journal of criminal court procedure, 2. 11-18 [in Ukrainian].

11. Ustinov, A. V. (2010). Juridicheskaja sila dokazatel'stv, poluchennyh na teritorii inostrannogo gosudarstva pri mezhdunarodnom sotrudnichestve po ugolovnym delam. [in Russian].

12. Konventsiia pro pravovu dopomohu i pravovi vidnosyny u tsyvilnykh, simeinykh ta kryminalnykh spravakh vid 22 sichnia 1993 . <https://zakon.rada.gov.ua/ laws/show/997_009> [in Ukrainian].

13. Boister, N. (2012). An introduction to Transnational Criminal Law. Oxford: University Press [in English].

14. Yevropeiska konventsiia pro peredachu provadzhennia $\mathrm{u}$ kryminalnykh spravakh vid 15 travnia 1972 r. <https://zakon.rada.gov.ua/laws/show/994_008> [in Ukrainian].

15. Konventsiia Organizaciyi Obyednanyh Nacij pro borotbu proty nezakonnogo obigu narkotychnyh zasobiv i psyhotropnyh rechovy`n. Ofitsiinyi veb-sait Verkhovnoi Rady Ukrainy. < https://zakon.rada.gov.ua/laws/show/995_096> [in Ukrainian].

16. Mizhnarodna konventsiia pro borotbu $\mathrm{z}$ aktamy yadernoho teroryzmu vid 13 kvitnia 2005 r. <https://zakon.rada.gov.ua/laws/show/995_d68>. [in Ukrainian].

17. Konventsiia Orhanizatsii Obiednanykh Natsii proty koruptsii vid 31 zhovtnia 2003 r. <https://zakon.rada.gov.ua/laws/show/995_c16> [in Ukrainian].

18. Konventsiia pro kiberzlochynnist' vid 23 lystopada 2001 r. Ofitsiinyi veb-sait Verkhovnoi Rady Ukrainy.< https://zakon.rada.gov.ua/laws/show/994_575> [in Ukrainian].

19. Yevropeiska konventsiia shchodo vidshkoduvannia zbytku zhertvam nasylnytskykh zlochyniv vid 24 lystopada $1983 \mathrm{r}$. <https://zakon.rada.gov.ua/laws/show/ 994_319> [in Ukrainian]. 
V. Popko, Philosophy Doctor at international law, Associate professor of the department of the comparative law and the European Union law of the Institute of International Relations, National Taras Shevchenko University of Kyiv e-mail: vadympopko@gmail.com; ORCID ID:0000-0001-8358-7721

\section{Principles of international state cooperation in providing mutual legal assistance in transnational criminal law}

The article deals with the principles of international cooperation of states on the provision of mutual legal assistance in transnational criminal law. The theoretical and methodological substantiation of this problem is given, the principles of international cooperation and their consolidation in international legal acts are analyzed, and the leading role of the United Nations in the international cooperation of the states is determined. The concept of "mutual legal assistance to states" is considered as an independent category of international criminal law in the mechanism of intergovernmental cooperation. The author highlights the following principles of international cooperation in the provision of legal aid as reciprocity of cooperation, voluntary implementation, observance of national sovereignty and security, the possibility of applying foreign legislation (assignment of sovereignty), compliance of the requesting state with the legislation of the requested state, equality of powers of the competent authorities, legal protection, implementation the terms of the agreement with the help of a national state, the effect of an international treaty only on the territory of States - its participants, cooperation on the basis of the law, provided by an international treaty, observance of legality. Important acknowledgment is the mutual recognition of the legal validity of official documents between the states, the speed of the provision of legal aid, the principle of equality of evidence obtained abroad in legal assistance, and others.

The main sources of transnational criminal law, which define the basis for cooperation on the provision of mutual legal assistance, are recognized by international conventions, including regional, bilateral assistance agreements and the internal law of states. Among the numerous international instruments that contain provisions on cooperation in combating or overcoming a form of transnational crime and complement each other in this area, important attention is paid to the UN Convention against Transnational Organized Crime of November 15, 2000 , which provides for provisions on the peculiarities of cooperation between States in the sphere of mutual assistance in criminal cases for certain categories of crimes. The conclusions state that the comprehensive regulation of international cooperation in the fight against transnational crime is under development, the main tasks in the field of assistance are the consolidation of international standards in national criminal procedures, improvement of cooperation on mutual legal assistance, and improvement of coordination of work of national law enforcement agencies.

Keywords: transnational criminal law; principles; crime; convention; cooperation; legal assistance; state collaboration.

Надійшла до редакції 21.05.2019

(c) Попко В. B., 2019 